\title{
A calibrated composite section for the Late Jurassic Reuchenette Formation in northwestern Switzerland (?Oxfordian, Kimmeridgian sensu gallico, Ajoie-Region)
}

\author{
Markus Jank ${ }^{1}$, Andreas Wetzel ${ }^{2}$ \& Christian A. Meyer ${ }^{3}$
}

Key words. Stratigraphy, biostratigraphy, Kimmeridgian, Jurassic, NW Switzerland, Banné Marls, Virgula Marls, Reuchenette Formation

\begin{abstract}
A new stratigraphical frame for Kimmeridgian sediments of northwestern Switzerland has been established by correlating seventeen closely spaced sections by means of lithological, sedimentological, and microfacial data as well as by ammonites. This newly established stratigraphical frame is of great value, because these sediments are usually characterised by a prominent sparseness of index-fossils (i.e. ammonites).
\end{abstract}

The biostratigraphical frame is based on seven species of ammonites and corroborated by ostracodes. The investigated sedimentary record is divided into nine intervals and assigned to the Late Oxfordian to Late Kimmeridgian sensu gallico (middle Eudoxus-Zone). Exact lithological correlations between the outcrops are achieved by three marker beds.

The new stratigraphical frame is a pre-requirement for refining correlations of sections, for reconstructing sea level fluctuations, and for quantifying synsedimentary differential subsidence.

\section{Introduction}

The thickness of the Reuchenette Formation in the southern and central Jura Mountains in northwestern Switzerland varies from about $40 \mathrm{~m}$ in the region of Solothurn (Gygi \& Persoz 1986; Meyer C. A. 1993) to about $160 \mathrm{~m}$ in the region of Biel (quarry La Reuchenette near Péry BE; Thalmann 1966). Recent investigations of Mesozoic sediments in the Jura Mountains show, or at least suggest, that depo-centres migrated with time and that thickness variations are spatially related to Permo-Carboniferous subcrop structures, which probably became reactivated (Gonzalez 1993; Wetzel et al. 1993, 2003; Allia 1996; Burkhalter 1996; Pittet 1996; Allenbach 2002).

The Reuchenette Formation was introduced by Thalmann (1966) to replace the Kimmeridgian auctorum without changing its boundaries and "fixing" the sediments biostratigraphically. Consequently, the rarity of index-fossils within the Reuchenette Formation - even the type-section in the quarry La Reuchenette near Péry BE (No. X in Fig. 1) does not yield any index-fossils - led to numerous, but different suggestions as how to subdivide the sediment column, to correlate the stra- ta, and to assign their age (e.g. Thurmann 1832; Greppin 1870; Häfeli 1966, Thalmann 1966; Chevallier 1989; Meyer C.A. 1989; Gygi 2000b). As ammonites are rare in shallow-water platform carbonates that accumulated mainly in a restricted setting, correlation over small distances relies on lithology. Recently, sequence-, cyclo- and mineralo-stratigraphy were used in addition for correlation (Gygi \& Persoz 1986; Gygi 1995; Mouchet 1995, 1998; Gygi et al. 1998; Meyer M. 2000; Colombié 2002). These studies, however, are based on only a few reliable high-resolution biostratigraphical markers, most of them unfortunately occurring in distant and/or small outcrops and/or have different biostratigraphical resolution and ages. Therefore, a precise high-resolution chronostratigraphical correlation over larger distances is difficult to establish. The age assignment of Kimmeridgian platform sediments was attempted by benthic foraminifera (Tschudin 2001) and by the very rare ammonites (Gygi 1995, 2000b).

Therefore, a reliable biostratigraphical framework for Kimmeridgian sediments in NW Switzerland is still lacking with all consequences for their correlation.

\footnotetext{
1 Markus Jank, Geologisch-Paläontologisches Institut Universität Basel, Bernoullistrasse 32, CH-4056 Basel, Switzerland. E-mail: janmar@gmx.ch

2 Andreas Wetzel, Geologisch-Paläontologisches Institut Universität Basel, Bernoullistrasse 32, CH-4056 Basel, Switzerland.

E-mail: andreas.wetzel@unibas.ch

3 Christian A. Meyer, Naturhistorisches Museum Basel, Augustinergasse 2, CH-4001 Basel, Switzerland. E-mail: christian.meyer@bs.ch
} 
Since the beginning of the Transjurane motorway project, new large outcrops in the Ajoie-Region expose the shallowwater limestones of the Reuchenette Formaton very well. The exposures are closely spaced and perfectly suited to study these sediments, and they contain index-fossils. It is the purpose of this paper to provide a general lithological and a refined/precise biostratigraphical frame for the sediments of the Reuchenette Formation in the Ajoie-Region by means of lithological, sedimentological, and microfacial data and by ostracodes and in situ collected ammonites. The new biostratigraphical framework is essential for the Jura Mountains and adjacent areas as it allows the re-evaluation of existing and recent data.

\section{Geological Setting}

The study area is located at the transition from the Folded Jura Mountains to the Tabular Jura of northwestern Switzerland (Ajoie-Region; Fig. 1). During the Late Jurassic, the area was covered by a shallow epicontinental sea between the Tethys in the south and the Paris Basin in the north and northwest (e.g. Ziegler 1990). Under subtropical conditions (e.g. Frakes et al. 1992) mainly carbonates and some marls accumulated on the Kimmeridgian platform. The development in the Thitonian, Portlandian and Cretaceous is poorly known, because during the Tertiary, or probably even before, the study area was subjected to weathering and erosion that removed the uppermost Late Kimmeridgian deposits; it is not known how much has been eroded.

In the Ajoie-Region the shallow-water limestones of the Reuchenette Formation rest on the Courgenay Formation (Fig. 2). The top of the Courgenay Formation (Porrentruy Member sensu Gygi 1995) consists of massive, white, chalky limestones (Gygi 1995, 2000b). The top of the Reuchenette Formation is eroded and overlain by Tertiary sediments. In the southern and central Jura Mountains, the Reuchenette Formation is composed of well-bedded, grey and white limestones. They rest on the Balsthal Formation and are followed by the Twannbach Formation. The top of the Balsthal Formation (Verena Member sensu Desor \& Gressly 1859; in Gygi 2000c) is composed of oo-oncolitic carbonates and grades laterally into the sediments of the Porrentruy Member (Fig. 2). The Twannbach Formation consists of $\mathrm{cm}$-dm thick layers of darkgrey micritic limestones (Thalmann 1966).

Thalmann (1966) defined the Reuchenette Formation in the limestone quarry of La Reuchenette near Péry BE as a monotonous succession of bedded limestones with few and thin marl intercalations. Lime mudstone (sensu Dunham 1962) is the dominant lithology there, but peloidal wacke- to grainstones and some oolitic horizons occupy some prominent intervals. Coral biostromes are uncommon (Gygi \& Persoz 1986). The base of the Reuchenette Formation is marked by an uneven erosion surface (Thalmann 1966) overlain by a massive $18 \mathrm{~m}$ thick limestone unit (Gygi \& Persoz 1986). Locally a horizon with blackened lithoclasts is developed in the basal

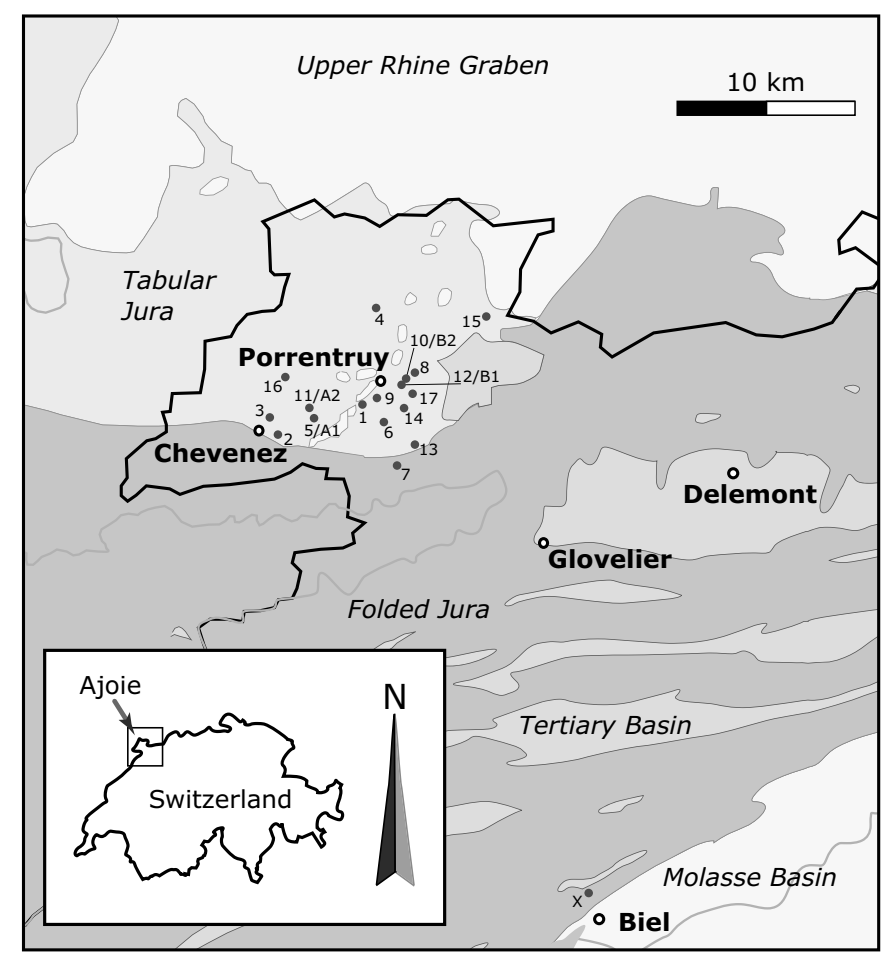

Fig. 1. Geological overview map and Swiss coordinates of locations and geological transects. Note the altitude difference (about $60 \mathrm{~m}$ ) between the base of Coregent (A1) and the base of the Virgule Marls (A2) in Sur Combed Ronde (note: layers are \pm horizontal; see Swiss geol. map 1085 St-Ursanne).

lower part (Gygi 1982, Colombié 2002). The lower $8 \mathrm{~m}$ of this massive unit are composed of oo-oncolitic carbonates (Verena facies). The upper $10 \mathrm{~m}$ are primarily mudstone with local patches of oolitic wackestone. Above this massive limestone unit, well-bedded mudstones and peloidal wacke-to grainstones with two bands of fenestrate stromatolites occur (Gygi 1982, Colombié 2002). The boundary between the massive unit and well-bedded limestones is conspicuous and it can be easily observed, whereas the horizon with blackened lithoclasts is restricted to a small part of the La Reuchenette quarry (Gygi \& Persoz 1986). This sharp lithological contrast is developed between the underlying members (i.e. Porrentruy and Verena Member) and the Reuchenette Formation in all sections in the Ajoie-Region and southern and central Jura Mountains (Gygi 2000 b, c). For this reason, Gygi defined the boundary between the Reuchenette Formation and the underlying Balsthal and Courgenay Formation at the base of the well-bedded limestones (Gygi 2000b, c). This boundary is visible in the quarry La Rasse south of Porrentruy (Section RG 340 of Gygi, Gygi 2000b, No. 9 in Fig. 1) and in Chemin Paulin near Courgenay (Section RG 350 of Gygi; Gygi 2000b, No. 7 in Fig. 1). The thickness of the Reuchenette Formation in terms of Gygi's boundaries is approximately $140 \mathrm{~m}$ at the type-section $\mathrm{La}$ Reuchenette. 


\begin{tabular}{|c|c|c|c|c|c|c|}
\hline & Code & Sections & \multicolumn{2}{|c|}{ Swiss Coordinates } & \multirow{2}{*}{$\begin{array}{c}\text { Altitude (m) } \\
457\end{array}$} & \multirow{2}{*}{$\begin{array}{l}\text { Interval(s) } \\
\text { top Thalassinoides Limestones, base } \\
\text { "Nautilidenschichten" }\end{array}$} \\
\hline 1 & BAN & Tunnel Le Banné (Westportal), base & 571.833 & 250.504 & & \\
\hline 2 & $\mathrm{CHV}$ & La Combe (Carrière Combe de Varu), base & 567.753 & 248.930 & 491 & $\begin{array}{l}\text { Nerinean Limestones... Oyster } \\
\text { Limestones }\end{array}$ \\
\hline 3 & CHVs & Chevenez (La Scierie), base & 567.175 & 249.675 & & $\begin{array}{l}\text { Lower Grey and White Limestones, } \\
\text { base Banné Marls }\end{array}$ \\
\hline 4 & COE & Coeuve (Carrière), base & 574.725 & 256.075 & & $\begin{array}{l}\text { top Thalassinoides Limestones, } \\
\text { "Nautilidenschichten" }\end{array}$ \\
\hline 5 & CRE & Creugenat, base (= A1) & 569.173 & 249.748 & 449 & $\begin{array}{l}\text { top Thalassinoides Limestones, base } \\
\text { "Nautilidenschichten" }\end{array}$ \\
\hline 6 & FON & Fontenais (Carrière communale), base & 573.050 & 249.575 & & $\begin{array}{l}\text { top Thalassinoides Limestones, base } \\
\text { "Nautilidenschichten" }\end{array}$ \\
\hline 7 & PAU & Chemin Paulin & 573.790 & 247.100 & & Porrentruy Member... Banné Marls \\
\hline 8 & PMS & Pré Monsieur (Carrière), base & 574.887 & 252.262 & 437 & Coral Limestones \\
\hline 9 & RAS & La Rasse (Carrière) & 572.560 & 250.840 & & $\begin{array}{l}\text { Porrentruy Member... Lower Grey and } \\
\text { White Limestones }\end{array}$ \\
\hline 10 & RDM & Roches de Mars, base (= B2) & 574.372 & 252.021 & 427 & Nerinean Limestones, (Virgula Marls) \\
\hline 11 & SCR & Sur Combe Ronde, base Virgula Marls (= A2) & 568.869 & 250.082 & 511 & $\begin{array}{l}\text { top Nerinean Limestones, Virgula } \\
\text { Marls }\end{array}$ \\
\hline 12 & TUP & Cras d'Hermont (base little road) & 573.958 & 251.694 & 443 & $\begin{array}{l}\text { "Nautilidenschichten", Lower Grey and } \\
\text { White Limestones }\end{array}$ \\
\hline 12 & TUP & $\begin{array}{l}\text { Cras d'Hermont (end little road), base Banné } \\
\text { Marls (= B1) }\end{array}$ & 574.108 & 251.750 & 456 & base Banné Marls \\
\hline 12 & TUP & $\begin{array}{l}\text { Cras d'Hermont (block between motorway } \\
\text { and car shop) }\end{array}$ & 574.058 & 251.797 & 447 & $\begin{array}{l}\text { top Banné Marls, base Nerinean } \\
\text { Limestones }\end{array}$ \\
\hline 12 & RDMa & Cras d'Hermont (car shop) & 573.970 & 251.844 & 445 & base Nerinean Limestones \\
\hline 13 & VAB & L'Alombre aux Vaches (Carrière Vabenau) & 574.800 & 248.200 & & $\begin{array}{l}\text { top Thalassinoides Limestones... } \\
\text { Banné Marls }\end{array}$ \\
\hline 14 & VAT & Vatelin (Carrière) & 574.300 & 250.500 & & $\begin{array}{l}\text { top Thalassinoides Limestones... } \\
\text { Lower Grey and White Limestones }\end{array}$ \\
\hline 15 & VEN & Vendlincourt (Carrière), base & 578.950 & 255.475 & & $\begin{array}{l}\text { top "Nautilidenschichten"... Banné } \\
\text { Marls }\end{array}$ \\
\hline 16 & VTT & Vâ tche Tchâ (Combe de Vâ tche Tchâ) & 568.720 & 252.155 & & Banné Marls \\
\hline 17 & $\mathrm{BDH}$ & Bas d'Hermont (Carrière) & 574.600 & 251.000 & & $\begin{array}{l}\text { top Thalassinoides Limestones, base } \\
\text { "Nautilidenschichten" }\end{array}$ \\
\hline $\mathbf{x}$ & REU & La Reuchenette (Carrière) & 585.890 & 226.240 & & Type-section \\
\hline
\end{tabular}

Fig. 1. Coninued

\section{Methods and Material}

Seventeen outcrops were studied for their lithological, sedimentological, and facies record (Fig. 1). Twelve outcrops were measured and sampled in detail for polished slabs and thin sections.

The evaluation of the Standard Microfacies Types and the facies (Fig. 3) of approximately 500 thin sections are based on the classifications of Dunham (1962), Wilson (1975), and Flügel (1982). The interpretations of thin sections and depositional environments are illustrated by "Facies-Patterns" on the right column of the figures. The term "bedding" is used to describe the internal characteristics/composition of a bed, e.g. flaser bedding, nodular bedding, cross bedding, laminated. The term "layering" is used to characterize the thickness of a bed, e.g. massive-layered $(>1 \mathrm{~m})$, thick-layered $(0.3-1 \mathrm{~m})$, thin-layered $(1-3 \mathrm{dm})$, very thin-layered $(<1 \mathrm{dm})$. Two geological transects (see Fig. 1; A1-A2, B1-B2) were evaluated to obtain an independent information about the regional trends in thickness.

Ammonites were collected by M. Jank, B. Hostettler (Fondation Paléontologique Jurassienne) and the Section de

Paléontologie de la République et du Canton Jura (SPA). The taxonomic assignment was made by G. Schweigert (Staatliches Museum für Naturkunde, Stuttgart; Schweigert et al., in prep.). Ten marl samples were dissolved in $\mathrm{H}_{2} \mathrm{O}_{2}$ and ostracodes were collected from the outwash samples (fractions between 100 and $400 \mu \mathrm{m}$ ) in order to obtain an independent age-control. U. Schudack (Berlin, Germany) made the taxonomic determination and biostratigraphical interpretation.

The sections of La Rasse (No. 9 in Fig. 1) and Chemin Paulin (No. 7 in Fig. 1) were already measured and briefly described by Gygi (2000b). Some of the data added in these profiles consist of observations made on samples and field descriptions by Gygi, stored in the Natural History Museum Basel. The sections of La Rasse, Chemin Paulin and Bas d'Hermont (No. 17 in Fig. 1) were re-investigated to detect marker beds.

As the position of the boundary between the Courgenay Formation and the Reuchenette Formation is a matter of debate (Thalmann 1966; Gygi 2000b, c), this work follows Gygi (see above). 


\begin{tabular}{|l|l|l|lll}
\hline Series & $\begin{array}{l}\text { Ammo- } \\
\text { nite } \\
\text { Zones }\end{array}$ & $\begin{array}{l}\text { Forma- } \\
\text { tion }\end{array}$ & Canton Jura (NW) & Canton Bern & Canton Solothurn (SE) \\
\hline
\end{tabular}

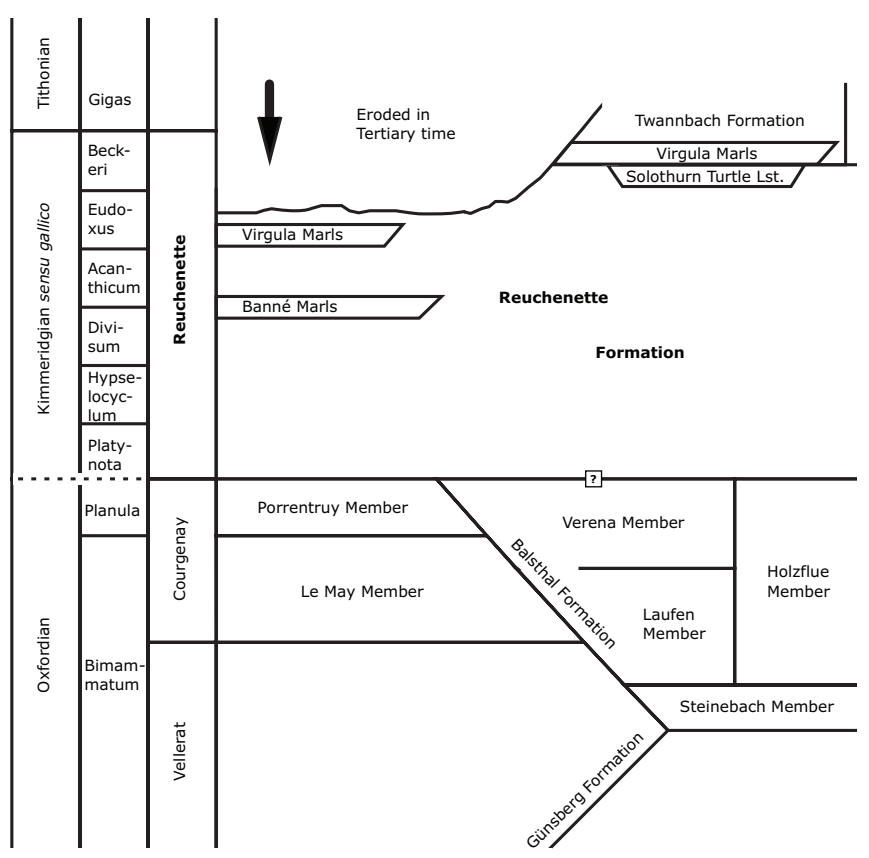

Fig. 2. Chrono-, litho- and biostratigraphical scheme for the Reuchenette Formation, based on data from Gygi (2000b), Meyer C.A. (1990, 1993) and this study. Arrow indicates position of the measured sections. The biostratigraphical position of the lithological boundary between the Reuchenette Formation and the Courgenay/Balsthal Formation is not proved; even the lithological boundary itself is a matter of debate. The associated thickness-relation in the Ajoie- and Solothurn-Region and are not to scale (difference about $100 \mathrm{~m}$; compare introduction and results).

The composite section has been subdivided into nine intervals (see Fig. 4) that are named by characteristic features such as colour, fracturing, marl content or fossil content (Plate 1).

\section{Lithology}

Most of the lithologies are difficult to differentiate in the field outside road cuts and quarries; in addition, intense weathering often obliterates the typical features. Consequently, in the different outcrops the boundaries between the intervals are occasionally diffuse and changes are gradual. The upper four intervals are only visible in La Combe (Figs 4 and 5).

Porrentruy Member (top of the Courgenay Formation sensu Gygi 1995):

In the Ajoie-Region, the Porrentruy Member is composed of smoothly fracturing, massive, white, calcarenitic and micritic, chalky limestones with Nerinean gastropods, small oncoids and coated intraclasts (Fig. 6). The latter two occasionally display brownish rims.
Thalassinoides Limestone $(\approx 30 \mathrm{~m})$ (Plate $1, \mathrm{a})$ :

The Reuchenette Formation starts with monotonous, thick- to massive-layered (m-thick), well-bedded, bioturbated, grey, micritic limestones with some bioclasts and reddish brown or greyish, coarse-grained, pseudo-oolitic (mainly rounded intraclasts and peloids) pockets, patches and strings within a micritic matrix. Generally, macrofossils are rare. Thinto thick-bedded layers fracture conchoidally and commonly contain abundant Thalassinoides. These burrows are often filled with the coarse-grained pseudo-oolitic material mentioned above. Between $22 \mathrm{~m}$ and $30 \mathrm{~m}$ (composite section; Fig. 4) several conspicuous horizons with Thalassinoides are filled with coarse spary cement (beds VAT-150, VAT-20, COE-240, COE-170, COE-180, VAB-40, VAB-30, RAS-25; see Fig. 4). Bed surfaces are often iron stained, occasionally bored and biogenically encrusted by oysters. About $9 \mathrm{~m}$ below the upper boundary of this interval, a 6-7 meters thick, white, chalky limestone with oncoids and coral clasts occurs within the monotonous, grey, micritic interval (e.g. beds RAS-45 to RAS-48; Fig. 4). In La Rasse another 3-4 m thick white layer is visible, intercalated into the grey limestones (beds RAS-57 to RAS60), as well. In Coeuve the top few meters bear a stromatolite layer.

\section{“Nautilidenschichten" ( $\approx 11 \mathrm{~m})$ (Plate $1, \mathrm{~b})$ :}

The "Nautilidenschichten" form dm- to m-thick layers. They are strongly bioturbated, marly micritic limestones and limestones with weakly internal nodular bedding. The lower part tends to exhibit marl-limestone alternations when weathered; calcarenitic (probably storm-influenced) marly limestones alternate with bioturbated marly micritic background sediment. This interval contains a rich bivalve fauna and large nautilids (Cenoceras sp.). Locally, bored and biogenically encrusted (by oysters) hardgrounds are intercalated. A significant 10-15 cm thick reddish brown storm lag deposit (beds COE-260, VAT-160, VAB-50, RAS-24, PAU $\approx 31$; Fig. 4) with strongly varying fossil content marks the boundary to the underlying interval (Figs. 7 and 8). This storm material is filled into Thalassinoides penetrating into the underlying bed. The upper part of the grey-coloured "Nautilidenschichten" is dominated by micrite and grades into the Lower Grey and White Limestones.

\section{Lower Grey and White Limestones $(\approx 11 \mathrm{~m})$ (Plate 1, c):}

This interval is composed of dm-to m-thick layers of grey and white, micritic and calcarenitic limestones with blocky fractures. Thalassinoides burrows are rare. Occasionally, the top is composed of stromatolitic limestones. The interval is capped by a regional hardground, which bored and biogenically encrusted by oysters.

Banné Marls (Banné Member sensu Marçou 1848; in Gygi 2000b, c) ( $\approx 8-9$ m) (Plate 1, d):

The slightly nodular Banné Marls comprise grey dm-thick layers of marlstones, calcarenitic marls and marly limestones 


\begin{tabular}{|c|c|c|c|}
\hline Facies & Bathymetry & Depositional environment & Facies association \\
\hline Intraclastic pack- to grainstones (-layer) & $\begin{array}{l}\text { shallow subtidal to } \\
\text { intertidal }\end{array}$ & lagoon & $\begin{array}{l}\text { Thalassinoides and storm } \\
\text { sediment association }\end{array}$ \\
\hline Lumachelle (shell bed) & $\begin{array}{l}\text { shallow subtidal to } \\
\text { intertidal }\end{array}$ & lagoon & $\begin{array}{l}\text { Thalassinoides and storm } \\
\text { sediment association }\end{array}$ \\
\hline $\begin{array}{l}\text { Bioclastic mud- and wackestones ( } \pm \text { in situ } \\
\text { macrofauna) }\end{array}$ & shallow subtidal & open lagoon and open platform & $\begin{array}{l}\text { Open lagoon and bight } \\
\text { association }\end{array}$ \\
\hline Chalky bioclastic mudstones with coral meadows & shallow subtidal & open lagoon or bight & $\begin{array}{l}\text { Open lagoon and bight } \\
\text { association }\end{array}$ \\
\hline $\begin{array}{l}\text { Marly bioclastic wacke- to packstones and float- to } \\
\text { rudstones with in situ macrofauna }\end{array}$ & shallow subtidal & protected lagoon or bight & $\begin{array}{l}\text { Open lagoon and bight } \\
\text { association }\end{array}$ \\
\hline $\begin{array}{l}\text { Bioclastic wacke- and packstones with in situ } \\
\text { macrofauna ( } \pm \text { argillaceous, slightly nodular) }\end{array}$ & shallow subtidal & open lagoon, next to shell shoals & $\begin{array}{l}\text { Open lagoon and bight } \\
\text { association }\end{array}$ \\
\hline $\begin{array}{l}\text { Oncoidal (chalky) wacke- to packstones and float- } \\
\text { to rudstones }\end{array}$ & $\begin{array}{l}\text { (very) shallow } \\
\text { subtidal }\end{array}$ & $\begin{array}{l}\text { restricted and relatively quiet } \\
\text { lagoon }\end{array}$ & $\begin{array}{l}\text { Rerstricted lagoon } \\
\text { association }\end{array}$ \\
\hline Peloidal mud- to grainstones & $\begin{array}{l}\text { intertidal and } \\
\text { shallow subtidal }\end{array}$ & $\begin{array}{l}\text { restricted, shallow lagoon and tidal } \\
\text { flat }\end{array}$ & $\begin{array}{l}\text { Rerstricted lagoon } \\
\text { association }\end{array}$ \\
\hline Non-laminated homogeneous micrite & $\begin{array}{l}\text { intertidal and very } \\
\text { shallow subtidal }\end{array}$ & $\begin{array}{l}\text { tidal pond and protected, quiet, } \\
\text { very shallow bight or lagoon }\end{array}$ & $\begin{array}{l}\text { Rerstricted lagoon } \\
\text { association }\end{array}$ \\
\hline Lensoidal pack-/rudstone & intertidal & $\begin{array}{l}\text { storm surge channel or rip channel } \\
\text { in a tidal flat environment }\end{array}$ & $\begin{array}{l}\text { Rerstricted lagoon } \\
\text { association }\end{array}$ \\
\hline Laminated mudstones & $\begin{array}{l}\text { supratidal and } \\
\text { intertidal }\end{array}$ & restricted platform areas & $\begin{array}{l}\text { Supra- and intertidal } \\
\text { platform area association }\end{array}$ \\
\hline Crumbly and platy mudstones and wackestones & $\begin{array}{l}\text { supratidal and } \\
\text { intertidal }\end{array}$ & mud flat or marsh deposit & $\begin{array}{l}\text { Supra- and intertidal } \\
\text { platform area association }\end{array}$ \\
\hline
\end{tabular}

Fig. 3. Facies-types and depositional environments; Reuchenette Formation, Ajoie-Region.

with a rich fauna of bivalves associated with some brachiopods, nautilids, echinoids, vertebrate remains (e.g. turtles, marine crocodiles), Thalassinoides and very rare ammonites. Shelly and calcarenitic horizons, probably reworked and winnowed by storms, are intercalated and commonly separate the beds.

Nerinean Limestones $(\approx 33 \mathrm{~m})$ (Plate $1, \mathrm{e})$ :

The Nerinean Limestone interval starts with $\mathrm{dm}$ - to $\mathrm{m}$ thick layers of grey, calcarenitic limestones $(\approx 10 \mathrm{~m}$; Fig. 9), followed by significant white, blocky fracturing, dm- to m-layered, chalky, calcarenitic limestones with large gastropods (Nerineans) and stromatolite layers (see Fig. 4). To the top it grades into greenish weathered, glauconite-rich pack- and grainstones with lumachelle intercalations (Fig. 10). This part shows characteristic, strongly bored and biogenically encrusted (by oysters), regional hardgrounds and cephalopods lying on them (Fig. 5).

Virgula Marls $(\approx 1 \mathrm{~m})$ (Plate $1, \mathrm{f})$ :

This characteristic marl interval bears a rich fauna of bivalves and cephalopods but small oysters (Nanogyra sp.) dominate. Vertebrate remains are often found. The marls are dark grey and form cm- to dm-thick layers. These marls correspond to the Virgula Marls mapped by Laubscher (1963).
Coral Limestones $(\approx 15 \mathrm{~m})$ (Plate $1, \mathrm{~g})$ :

The basal part of this interval comprises a few meters of dm-thick layers of grey, micritic limestones and intercalated bored and encrusted hardgrounds (probably regional extent). The Coral Limestones "sensu stricto" form a massive (m-thick) unit composed of thin- to thick-layered, blocky fracturing, white, and chalky, micritic limestones with corals, terbratulid and red-brown rhynchonellid brachiopods separated by thin marl seams. The aragonitic coral skeletons were dissolved and the voids then filled with calcite (e.g. Bathurst 1971). The interval grades into the Upper Grey and White Limestones.

Upper Grey and White Limestones ( $\approx 18 \mathrm{~m})$ :

This monotonous micritic interval exhibits m-thick layers. It is composed of three parts, whereas the middle part (beds CHV-1000 to 1200 in Figs. 4 and 5) is marly compared with the two other two parts. The limestones separate blocky with conchoidal surfaces. Fossils and Thalassinoides are sparse. A stromatolitic limestone with ripples capped by a hardground (biogenically encrusted by oysters) marks the top of this interval.

Oyster Limestones $(\approx 17 \mathrm{~m})$ (Plate $1, \mathrm{~h})$ :

This interval starts with massive (m-thick), calcarenitic limestones and a layer yielding Cladocoropsis mirabilis 

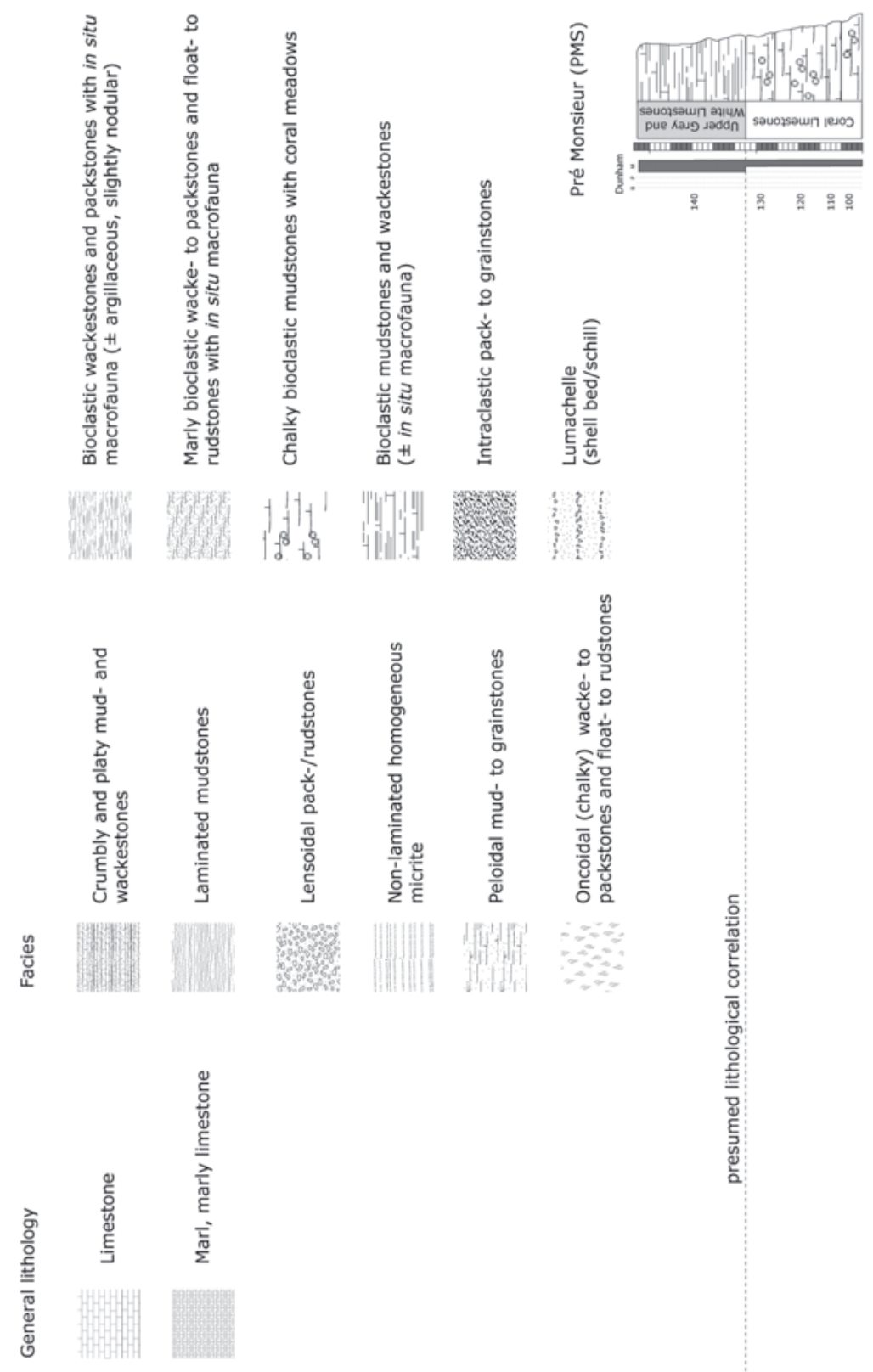


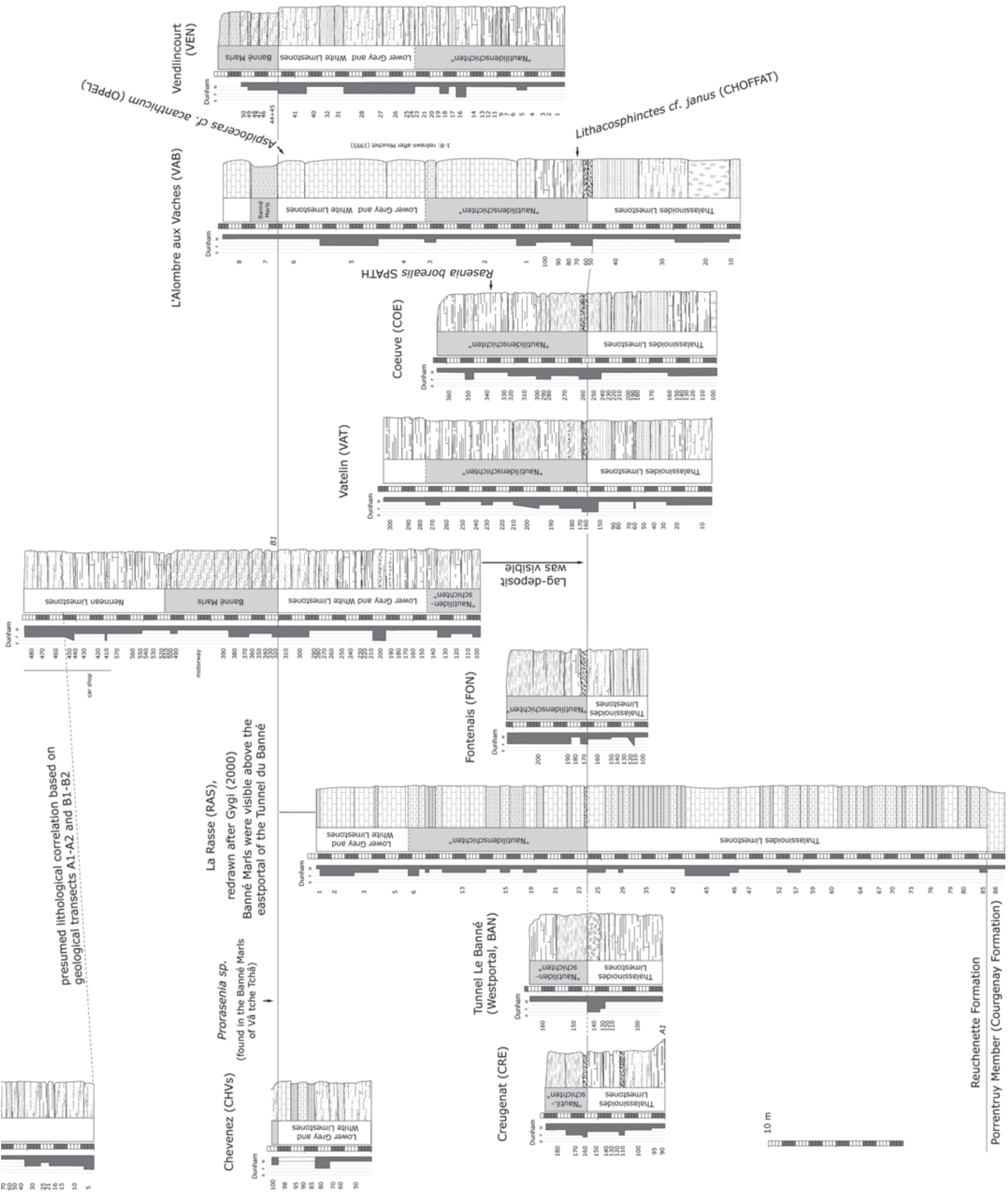

Fig. 4. Biostratigraphically subdivided composite overview for the sediments of the Reuchenette Formation in the Ajoie-Region. Detailed sections are published in PhD thesis of Markus Jank (Jank 2004). 

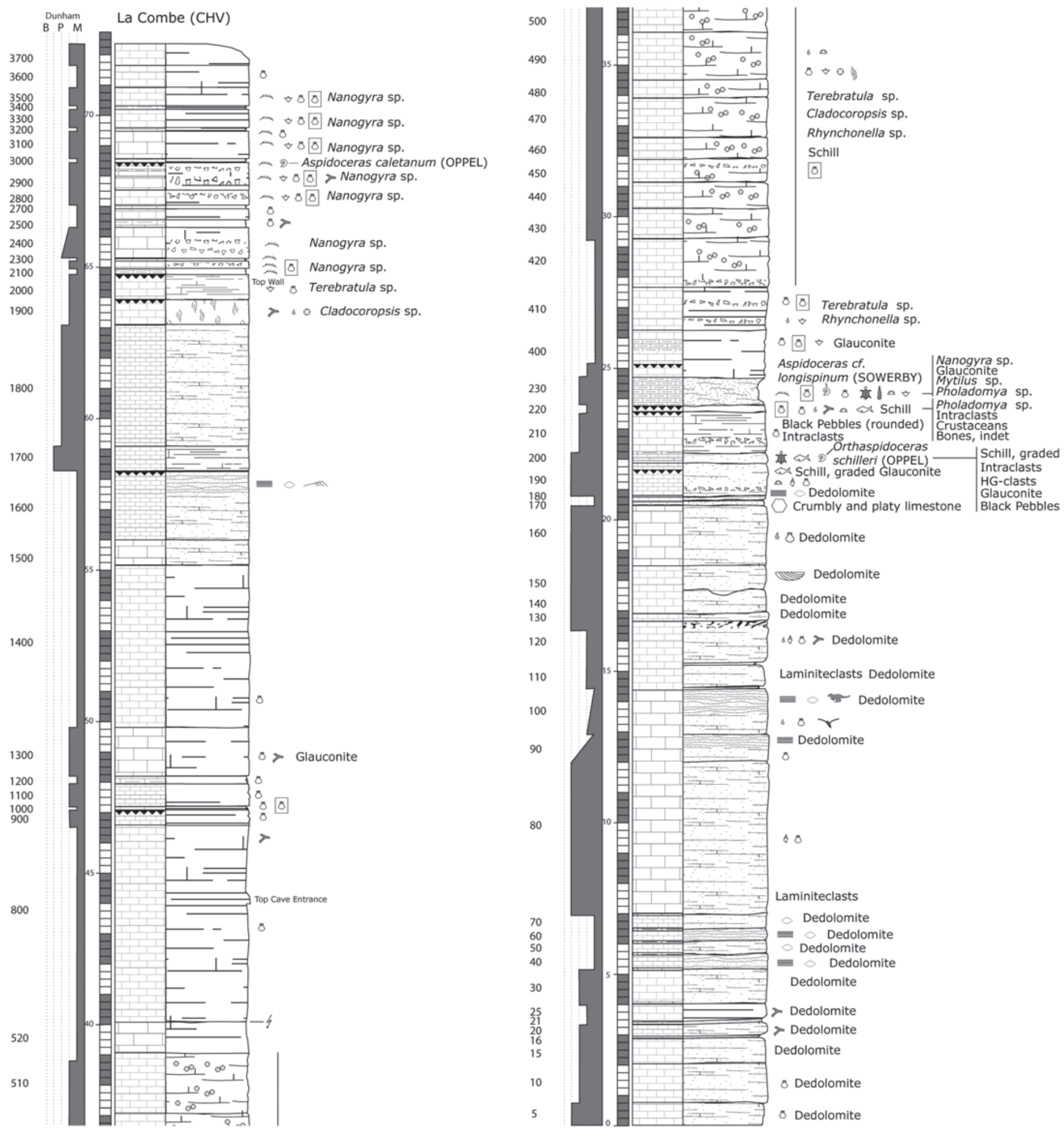

Fig. 5. Section La Combe - Bed CHV-230 are the Virgula Marls. For legend and symbols see Figs. 4 and 8. 


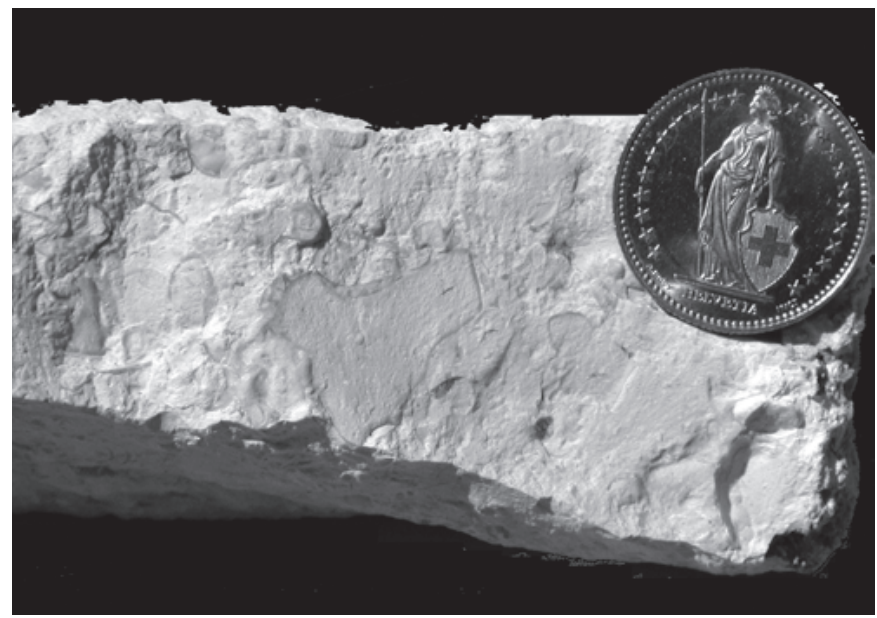

Fig. 6. White chalky limestone with angular and rounded intraclasts (bed RAS- 88 , La Rasse; scale: $\Delta \approx 2.5 \mathrm{~cm}$ ).

$(0-6 \mathrm{~m})$. It is overlain by $\mathrm{dm}$-thick layers of occasionally platy, marly, fine-grained (micritic) limestones, dominated by oysters.

\section{Biostratigraphy}

The biostratigraphical framework is provided by seven species of in situ collected ammonites (Fig. 11). Early Kimmeridgian sensu gallico is indicated by Lithacosphinctes cf. janus (CHOFFAT), Rasenia borealis SPATH and Prorasenia sp. (microconche of the family Aulacostephanidae). Aspidoceras cf. acanthicum (OPPEL) indicates the Divisum- and AcanthicumZone (pers. comm. G. Schweigert). Orthaspidoceras schilleri (OPPEL), Aspidoceras cf. longispinum (SOWERBY) and Aspidoceras caletanum (OPPEL) are indicative for the Acanthicum- and Eudoxus-Zones (Late Kimmeridgian sensu gallico). One specimen of Lithacosphinctes cf. janus (CHOFFAT) was found at the base of the "Nautilidenschichten" in L'Alombre aux Vaches (bed VAB-70; Fig. 4). One specimen of Rasenia borealis SPATH occurred near the top of the "Nautilidenschichten" in Coeuve (bed COE-340; Fig. 4). They indicate the Platynota-Zone and the Divisum-Zone. One specimen of Prorasenia sp. from the base of the Banné Marls in Vâ tche Tchâ also indicates the Divisum-Zone. The exact position of Aspidoceras $\mathrm{cf}$. acanthicum (OPPEL) is not clear, as Gygi \& Persoz (1986) state that one specimen "was taken by H. and A. Zbinden from a block which fell presumably from a marly limestone 1,5 $\mathrm{m}$ below the Banné Marls" in L'Alombre aux Vaches (see also Gygi 1995). After Mouchet (1995), the specimen is from the marly limestone $1,5 \mathrm{~m}$ below the Banné Marls in L'Alombre aux Vaches. Several specimens of Orthaspidoceras schilleri (OPPEL) were found on hardgrounds and in glauconitic beds below the Virgula Marls (beds RDM-200, CHV-200, beds in Sur Combe Ronde around 5-8 m; Figs. 4 and 5), indicating the Schilleri-Horizon of the late Acan-

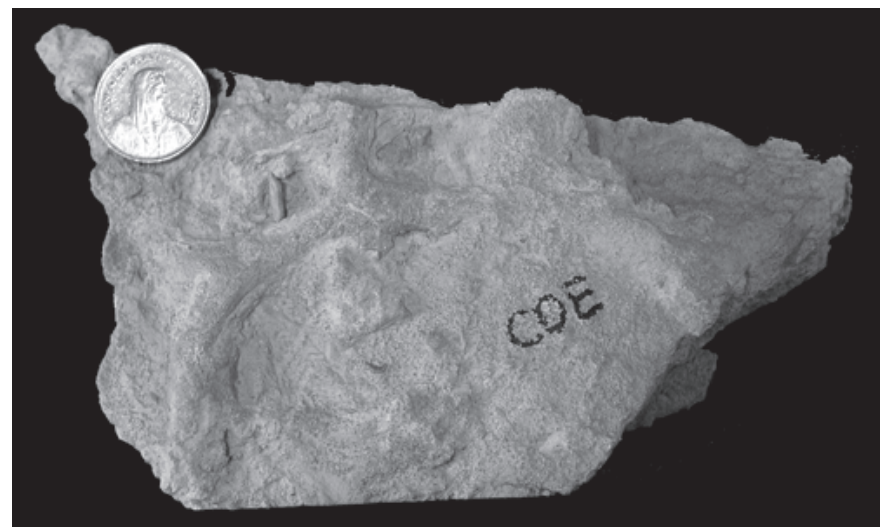

Fig. 7. Storm-lag deposit (intraclastic pack- to grainstone) with cast Thalassinoides (bottom side, positive hypichnia) - Important marker bed (bed COE260 , Coeuve; scale: $\Delta \approx 3 \mathrm{~cm}$ ).

thicum-Zone. One specimen of Aspidoceras cf. longispinum (SOWERBY) was found within the Virgula Marls (bed CHV230) and indicates the lowermost Eudoxus-Zone. Two specimens of Aspidoceras caletanum (OPPEL) point to the Caletanum-Horizon of the middle Eudoxus-Zone. One specimen was found in the Oyster Limestones in La Combe (bed CHV3000), the other one in the lowermost beds of the Coral Limestones right above the Virgula Marls in Sur Combe Ronde (beds in Sur Combe Ronde around 9 m; Fig. 4).

Due to low biostratigraphical resolution, ostracodes only vaguely agree with the ammonite data. They merely indicate the Early or Late Kimmeridgian sensu gallico (Fig. 12). Furthermore, the correlation between the ammonite-zones and ostracodes is not adequately established and remains a point of discussion (e.g. Weiss 1995), as illustrated by the biostratigraphical extension of ostracodes in beds RDM-200 and RDM-220 and the biostratigraphical position of Orthaspidoceras schilleri (OPPEL) also found in bed RDM-200 (Figs. 4, 11 and 12). For example, Amphicythere (Amphicythere) confundens OERTLI was found in Roches de Mars (beds RDM200, RDM-220) and it appears that it is not in contradiction to Orthaspidoceras schilleri (OPPEL) also found in bed RDM200 because Schudack (1994) describes a (litho)stratigraphical extension for Amphicythere (Amphicythere) confundens OERTLI from "Mittlerer Korallenoolith bis Unter-Kimmeridge", which corresponds approximately to the MutabilisZone/parts of the Acanthicum-Zone (Weiss 1995, 1996, 1997; Gramann et al. 1997).

\section{Results}

The stratigraphical correlation of the sections (Fig. 4) was established by the combination of lithological, facies and sedimentological criteria in combination with biostratigraphical data. This is exceptional because it is the first time that a large 
8 Bivalves
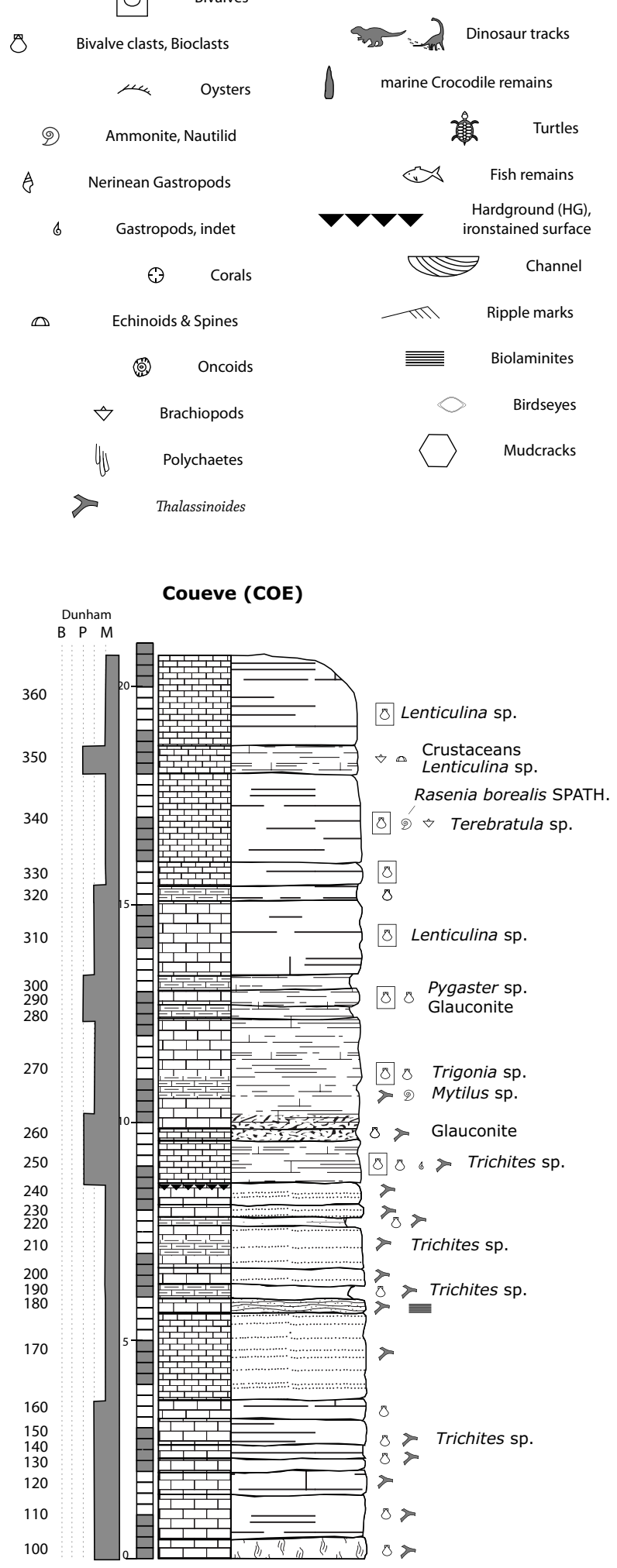

\section{Cras d'Hermont (TUP, RDMa)}

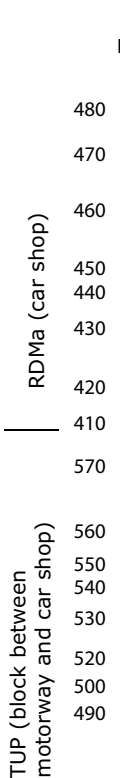

P M

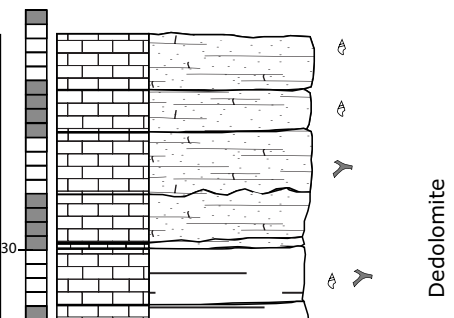

هั

8

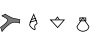

$A 2$

2

08

8 Dedolomite

Trichites sp. Isoperna sp.

Dedolomite

88

Motorway crosses the section:

approximated thickness

8 Lenticulina sp.

8

$\varnothing$ O Trichites sp.

$8>\otimes 8$ Trichites sp.

Glauconite

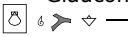

Glauconite

8 \& Harpagodes sp.

$>06$

28

Mytilus sp

Terebratula sp.

Lenticulina sp.

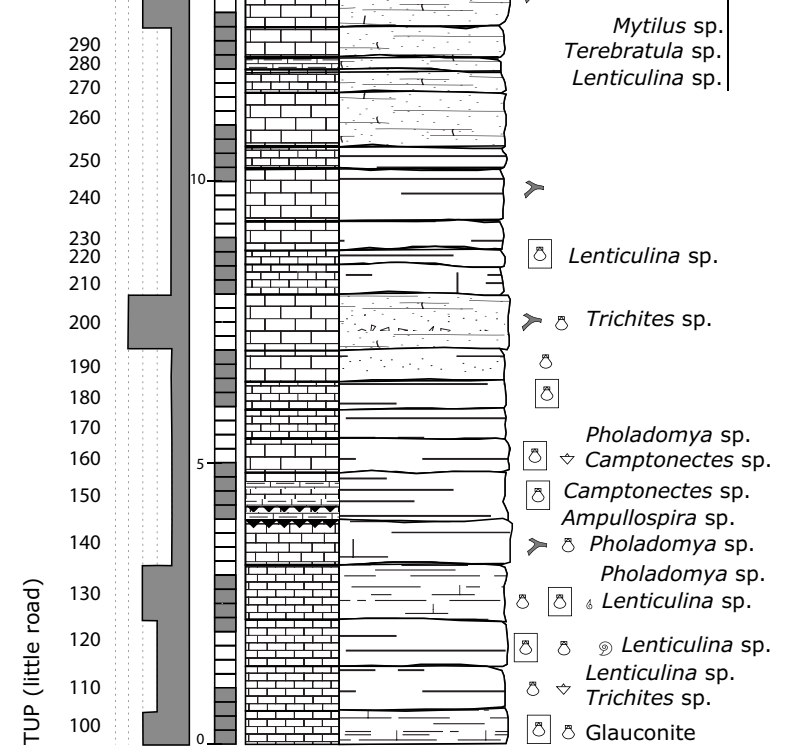

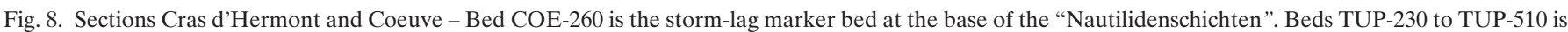
the Banné Marls. For legend see Fig. 4. 


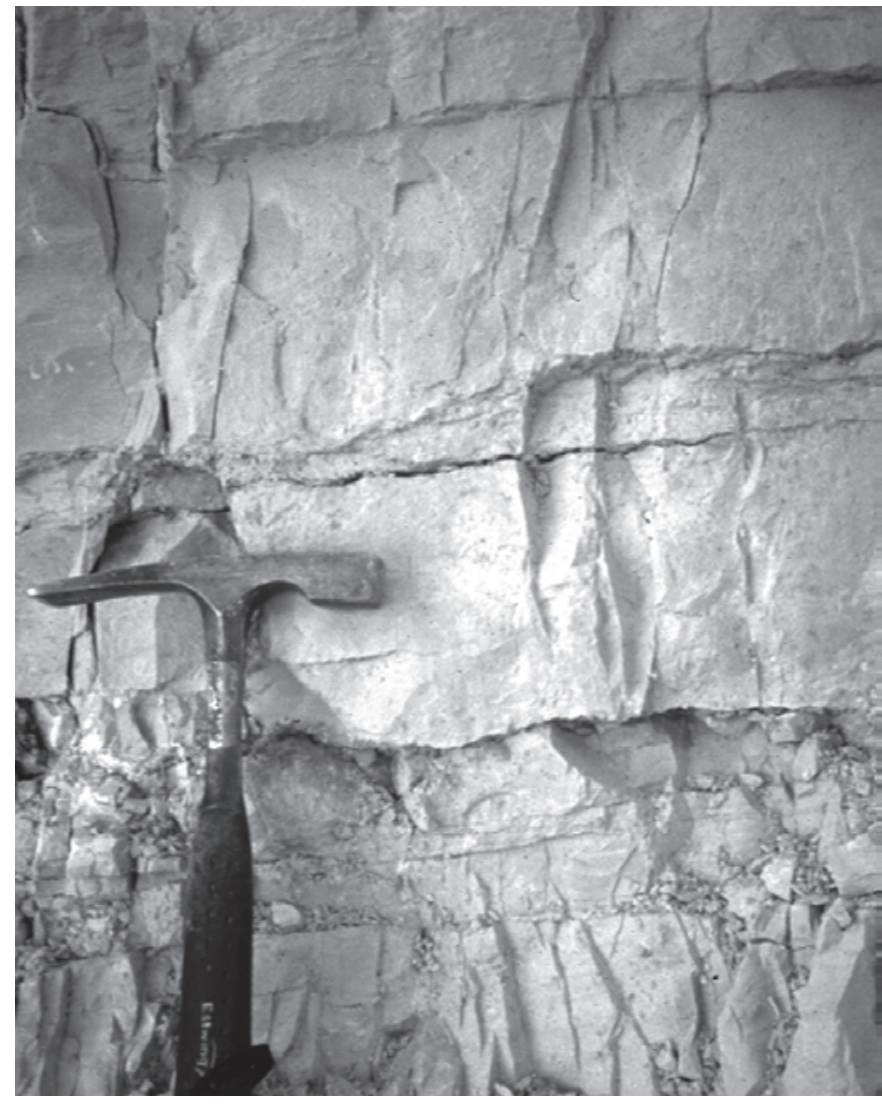

Fig. 9. Nerinean Limestones - Grey "sandy" limestone at the base of the Nerinean Limestone interval (base La Combe). Presumed lithological correlation with top Cras d'Hermont.

composite section of the sediments of the Reuchenette Formation can be biostratigraphically constrained by six bed-rock controlled ammonite occurrences (in situ collected).

Marker beds provide a lithological correlation between the outcrops. The sections Coeuve, La Rasse, L'Alombre aux Vaches, Vatelin, Creugenat, Fontenais, Chemin Paulin, Cras d'Hermont and Bas d'Hermont can be exactly correlated by the reddish brown, bioturbated, intraclastic wacke- to packstone storm-lag deposit at the base of the "Nautilidenschichten”. The Banné Marls connect the sections La Rasse, L'Alombre aux Vaches, Chemin Paulin, Vendlincourt, Vâ Tche Tchâ and Cras d'Hermont. The sections La Combe and Cras d'Hermont are correlated by coarser grained equally thick, calcarentic limestone beds within the Nerinean Limestone interval composed of peloidal wacke- to packstones. The second marl intercalation (Virgula Marls) allows lithological correlations between the sections La Combe, Roches des Mars and Sur Combe Ronde. The laterally homogeneous facies distribution, the vertical facies stacking pattern and lithological changes within close outcrops support these correlations.

The lithological correlation of the Virgula Marls is substantiated by the occurrence of Aspidoceras cf. longispinum

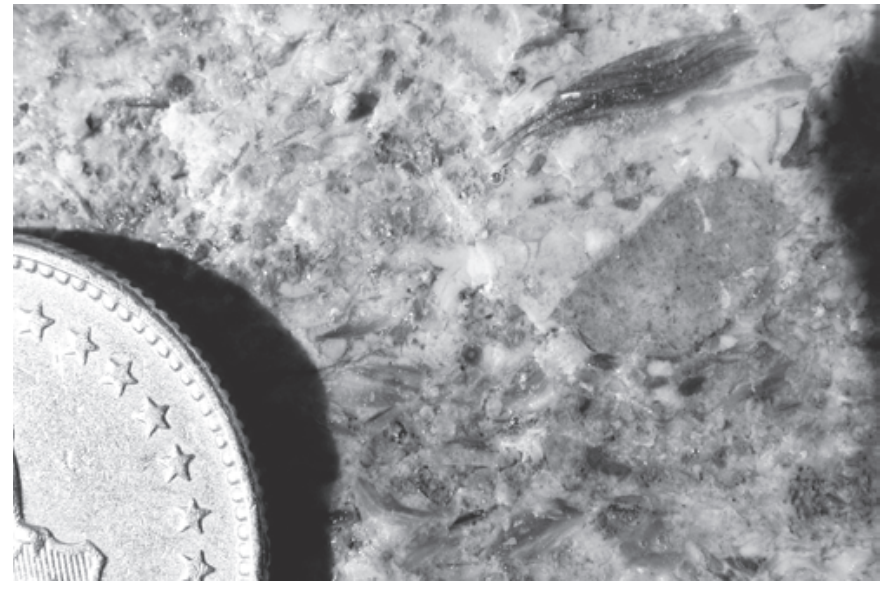

Fig. 10. Schill layer - Reworked material (right centre) from base of bed CHV-190 in shell-supported matrix (top of bed CHV-190, above hardground, La Combe; scale: $\Delta \approx 2.5 \mathrm{~cm}$ ).

(SOWERBY) and Orthaspidoceras schilleri (OPPEL) and some conspicuous hardgrounds (Fig. 5, beds CHV-190 to CHV-230). As indicated by Prorasenia sp. and Rectocythere (Rectocythere) iuglandiformis (KLINGLER), sedimentation of the Banné Marls at least started in the Divisum-Zone and probably continued in the Acanthicum-Zone. In the section La Combe Orthaspidoceras schilleri (OPPEL), Aspidoceras cf. longispinum (SOWERBY) and Aspidoceras caletanum (OPPEL) show that virgula-bearing sediments in the Jura Mountains differ in age. These ammonite finds also confirm that sediments between the Virgula Marls and Oyster Limestones are of Kimmeridgian age (Eudoxus-Zone) in the AjoieRegion, as mentioned by Gygi et al. (1998), regarding Laubscher's "Portlandien" (Laubscher 1963). Furthermore ammonites show that at least three different virgula-bearing levels exist in the Swiss Jura Mountains: two in La Combe (Virgula Marls, Oyster Limestones) and one in the type-section of La Reuchenette, where they were deposited below the boundary to the Twannbach Formation (Thalmann 1966).

Considering the short time span covered by the Caletanum-Horizon, the enormous thickness of the Coral Limestones and Upper Grey and White Limestones, is interpreted to be related to an important gain in accommodation space, resulting from sea level rise and enhanced subsidence (Jank, 2004).

Due to the lack of biostratigraphical data, the age of the lithological boundary (sensu Gygi; see above) to the Porrentruy Member remains vague. It is most probably within the Late Oxfordian (Jank 2004).

The "Nautilidenschichten" correspond to the "thick limestone beds with a rich fauna of bivalves and large nautilids in the old quarry adjacent to Fontenais cemetery south of Porrentruy" (Fontenais; No. 6 in Fig. 1), the "succession above sequence boundary K1" in the quarry La Rasse (Gygi et al. 1998), as well with the lowermost part of the quarry 


\begin{tabular}{|c|c|c|c|}
\hline \multicolumn{2}{|c|}{ TETHYAN DOMAIN } & & BOREAL DOMAIN \\
\hline \multirow{3}{*}{ 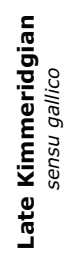 } & BECKERI & \multirow{4}{*}{$\begin{array}{l}\text { Aspidoceras caletanum (OPPEL), (f) } \\
\text { Aspidoceras cf. longispinum (SOWERBY), (e) } \\
\text { Orthaspidoceras schilleri (OPPEL), (d) } \\
\text { Aspidoceras cf. acanthicum (OPPEL) } \\
\text { Prorasenia sp., (c) } \\
\text { Rasenia borealis SPATH, (b) }\end{array}$} & AUTISSIODORENSIS \\
\hline & EUDOXUS & & EUDOXUS \\
\hline & ACANTHICUM & & MUTABILIS \\
\hline \multirow{3}{*}{ 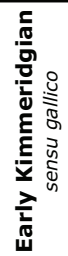 } & DIVISUM & & \multirow{2}{*}{ CYMODOCE } \\
\hline & HYPSELOCYCLUM & \multirow[b]{2}{*}{ Lithacosphinctes cf. janus (CHOFFAT), (a) } & \\
\hline & PLATYNOTA & & BAYLEI \\
\hline
\end{tabular}
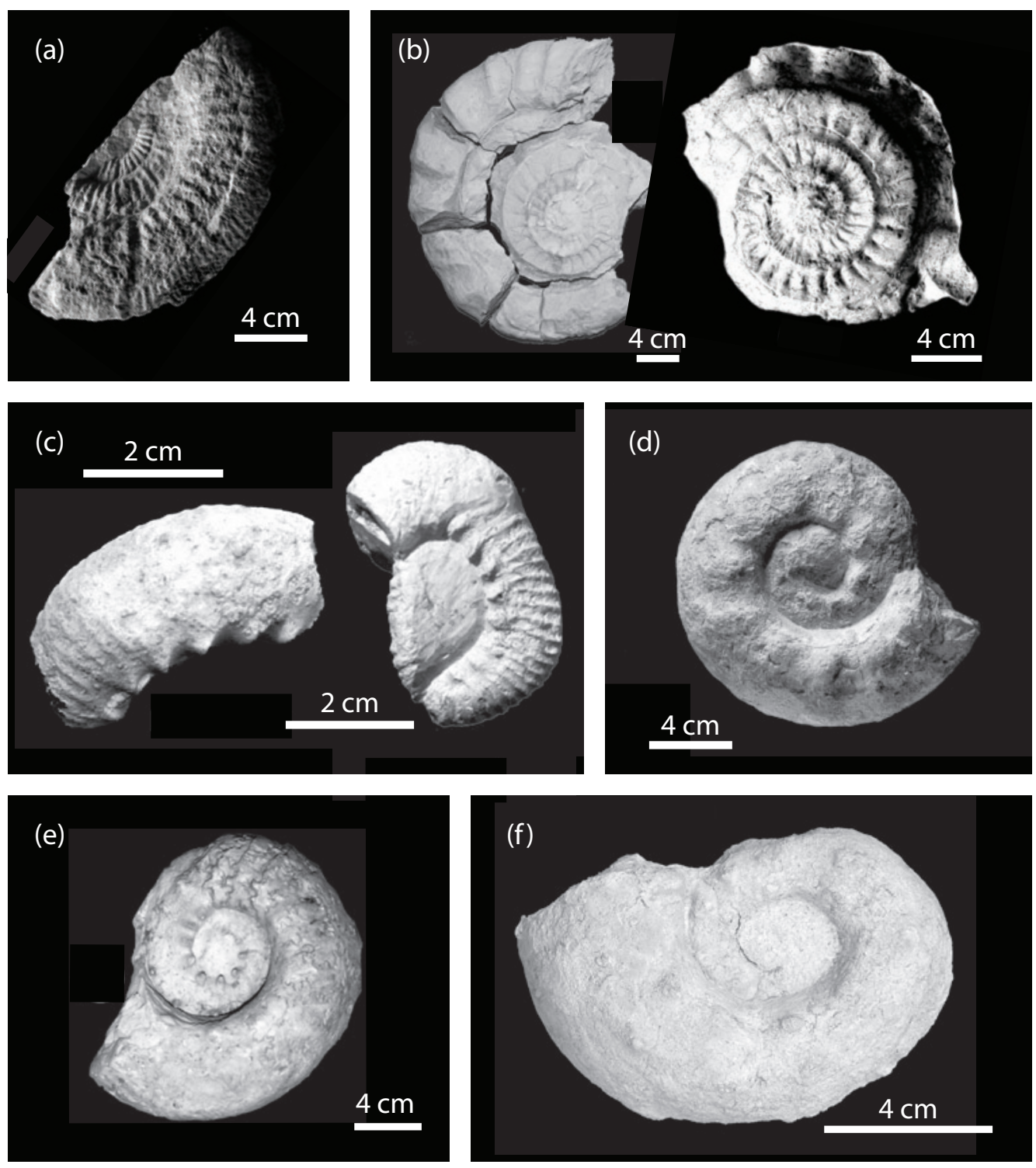

Fig. 11. Biostratigraphical frame based on ammonites. Zonation of the Kimmeridgian sensu gallico after Hantzpergue et al. (1997). Tethyan Domain is used sensu Domaine Téthysien, Province subméditerraneénne; Boreal Domain is used sensu Domaine Boréal, Province subboréale. All ammonites were collected in situ, except Aspidoceras cf. acanthicum (OPPEL) (Gygi 1995).

Exact biostratigraphical range and localities: (a) Lithacosphinctes cf. janus (CHOFFAT); PlatynotaZone; L'Alombre aux Vaches. (b) Rasenia borealis SPATH; DivisumZone; Coeuve. (c) Prorasenia sp.; Divisum-Zone; Vâ tche Tchâ. Aspidoceras cf. acanthicum (OPPEL); Divisum- to Acanthicum-Zone; L'Alombre aux Vaches. (d) Orthaspidoceras schilleri (OPPEL); Acanthicum-Zone, LallierianumSub-Zone, Schilleri-Horizon; La Combe (top bed CHV-190; (C) SPA, photo by B. Migy), Roches de Mars and Sur Combe Ronde. (e) Aspidoceras cf. longispinum (SOWERBY); lowermost Eudoxus-Zone; La Combe. (f) Aspidoceras caletanum (OPPEL); Eudoxus-Zone, Caletanum-Sub-Zone, Caletanum-Horizon; La Combe and Sur Combe Ronde (limestone about $1 \mathrm{~m}$ above the Virgula Marls; (C SPA). 


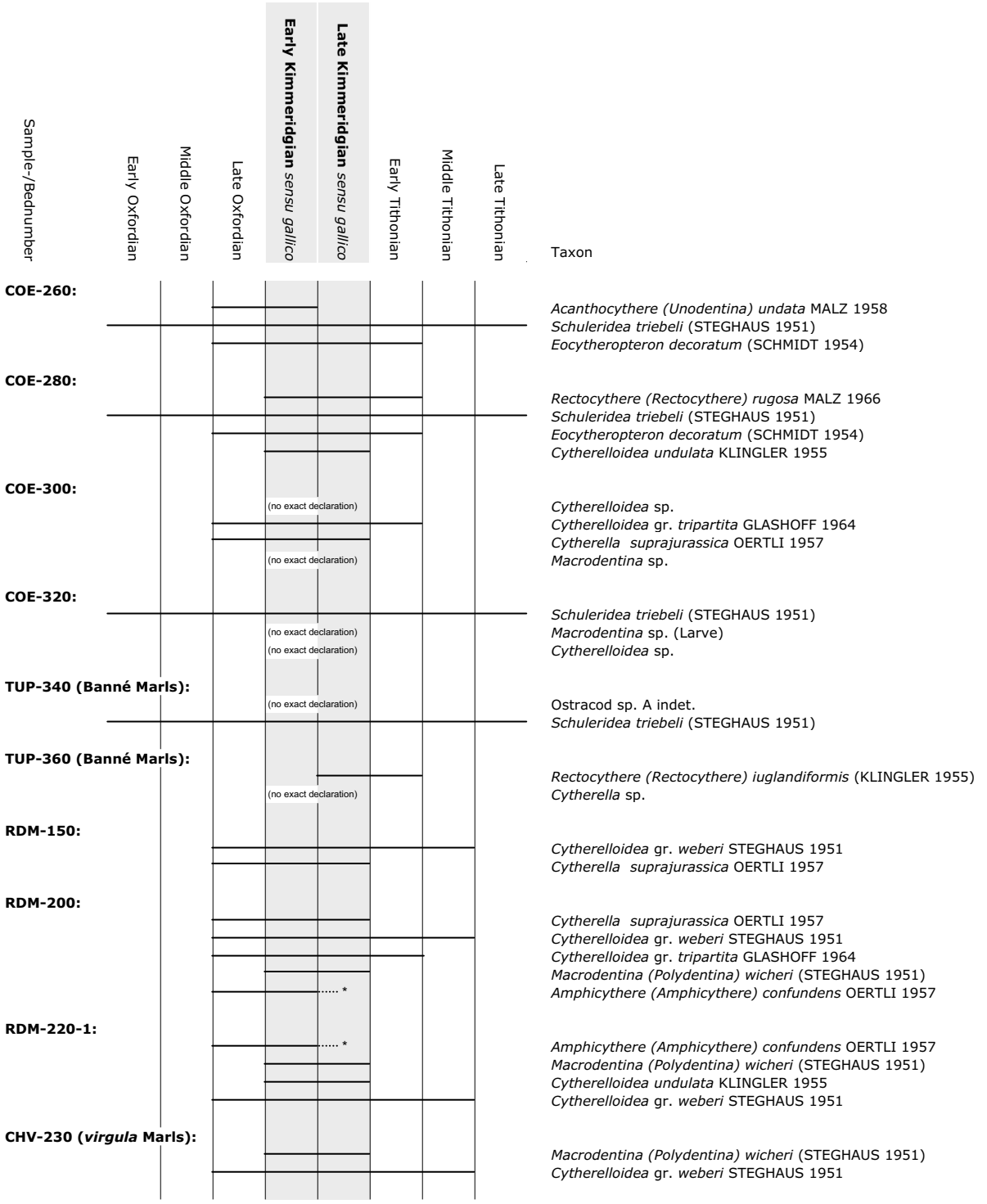

Fig. 12. Biostratigraphical framework given by range of some ostracodes. Note range of ostracode assemblage-zones vaguely agree with ammonite data. *Redrawn after Weiss $(1995,1996$ 1997) and Gramann et al. (1997).
Vabenau (Mouchet 1995, 1998) (L'Alombre aux Vaches; No. 13 in Fig. 1).

The multi-faceted facies of the sediments of the Reuchenette Formation in the Ajoie-Region represent an open to protected marine, very proximal platform setting within the Jurassic epicontinental realm of Central Europe. Facies, fauna and sedimentary structures are characteristic for shallow subtidal to supratidal settings and allow the distinction of 12 faciesentities.

Thickness estimates between the storm lag deposit at the base of the "Nautilidenschichten" (Fig. 1; point A1), the base of the Banné Marls (Fig. 1; point B1) and the base of the Virgula Marls (Fig. 1; point A2 and point B2) on the geological transects A1-A2 and B1-B2 independently confirm the thicknesses given by correlations based on marker beds. The thickness between the base of the Reuchenette Formation and the base of the Banné Marls of section Chemin Paulin (Gygi 2000b) independently corroborates the thickness between the base of the Reuchenette Formation and the base of the Banné Marls measured by correlating La Rasse, Cras d'Hermont and L'Alombre aux Vaches.

Based on all these data the thickness of the sediments of the Reuchenette Formation preserved in the Ajoie-Region is about $140 \mathrm{~m}$.

\section{Discussion}

The lithological correlations between the outcrops are in agreement with the biostratigraphical data. Nonetheless, the question arises, how reliable such lithological correlations are. Comparisons with modern environments are useful to illustrate the precision of such correlations, if lateral extent of facies belts, stacking patterns and event beds are considered. 
Investigations of recent shallow-marine carbonate systems show that lateral changes in facies may occur within ten's of kilometres (e.g. Harris \& Kowalik 1994), i.e. a specific facies shows lateral continuity of several kilometres, at least. For example, the carbonate mud facies on the Great Bahama Bank west of Andros Island occupies an area larger than $2700 \mathrm{~km}^{2}$ $(30 \mathrm{~km} \times 90 \mathrm{~km})$; the pellet-mud facies an area of about 3600 $\mathrm{km}^{2}$ (Purdy 1963a, b). In the German Muschelkalk, Aigner (1985) demonstrated that depositional cycles mainly composed of event beds correlate over ten's of kilometres. Modern tempestite deposits from Hurricane Kate (1985) are blanketing the peloidal packstone environment offshore of the Caicos tidal flat (Bahamas) (Wanless et al. 1988).

For the Ajoie-Region the facies imply that the platform topography can be considered as having been rather flat. The shallow-marine sediments probably built up close to sea level, filling accommodation space, which resulted in a generally flat topography. This in turn favoured a more or less uniform lateral facies development (i.e. no significant lateral facies changes have been observed). In addition, deposition on a flat topography is highly sensitive to low-amplitude relative sea level fluctuations leading to deposition of widespread and nearly synchronous beds similar in lithology and stacking pattern (Strasser et al. 1999). As the outcrops in the Ajoie-Region are closely spaced within the range of kilometres the lithological correlations appear to be reliable, especially when compared to modern analogues. At least three easily identifiable marker beds can be traced and used for exact lithological correlations.

\section{Conclusions}

The investigations provide a data set improving the knowledge of the sedimentary history of the Reuchenette Formation in the Swiss and French Jura, because the Reuchenette Formation was initiated by Thalmann (1966) to replace the Kimmeridgian auctorum.

The identification of the different depositional environments within a very shallow epicontinental sea with periodic emersion, allows defining marker beds useful for lithological correlations of biostratigraphically dated intervals over small distances. The sections provide a composite overview of the sedimentary record during the (? Planula) Platynota- to the Eudoxus-Zones: nine lithological intervals, seven in situ collected species of ammonites, and several marker horizons. The preserved thickness of the investigated sediments in the AjoieRegion is at least of $140 \mathrm{~m}$. It is still a matter of debate if the uppermost beds can be correlated with the type-locality at La Reuchenette (Jank, 2004). The observations also show that the boundary with the Porrentruy Member (Courgenay Formation) is still uncertain in terms of biostratigraphical age.

Nevertheless - taking into account that in situ index-fossils are very rare in the Kimmeridgian platform sediments of the Jura Mountains - this overview serves as a base for further refined investigations in terms of sea level fluctuations and synsedimentary differential subsidence (thickness variations and movement of depo-centres) and it offers the possibility to compare the sediments with other biostratigraphically constrained sections and outcrops in the Boreal and Tethyan realm.

\section{Additional Information}

Fossils of the beds CRE-160 and CRE-170 in Creugenat collected and determined during a palaeontological excavation field course by the Geologisch-Paläontologisches Institut University of Basel (GPI) in collaboration with the SPA are documented in the annual reports 2000 and 2002 of the SPA ("SPA" 2001; Marty 2003). The fossils found in the Banné Marls of Vâ Tche Tchâ and the Virgula Marls of La Combe are published in the annual reports of the SPA, as well (Marty \& Diedrich 2002).

The taxonomic determination of several fossils is still under discussion: see forthcoming annual reports and publications of the SPA, diploma thesis at the GPI of K. Stransky (in prep.), S. Thüring (in prep.) and R. Waite (in prep.), and the huge and extraordinary collection of B. Hostettler (Fondation Paléontologique Jurassienne).

Apart from the sections Chemin Paulin, Bas d'Hermont, Vâ tche all sections can be found in the PhD thesis of Markus Jank (New insights into the development of the Late Jurassic Reuchenette Formation of NW Switzerland - late Oxfordian to late Kimmeridgian, Jura Mountains). A hard copy can be obtained at the library of the GPI (address: Bibliothek, Geologisch-Palaeontologisches Institut der Universität Basel, Bernoullistrasse 32, CH-4056 Basel, Switzerland); an online version is available under http://pages.unibas.ch/diss/2004/ DissB_7365.htm.

\section{Repository}

The samples, thin sections and ostracode samples of this study are deposited at B. Hostettler (address: Fondation Paléontologique Jurassienne, Au Village 16, CH-2855 Glovelier, Switzerland). The ammonites are with B. Hostettler and the SPA (address: Office Cantonal de la Culture, Section de Paléontologie, Hôtel des Halles, Case postale 64, CH- 2900 Porrentruy, Switzerland).

\section{Acknowledgments}

A part of this work has been carried out in the frame of collaboration between the University of Basel and the Section de Paléontologie de la République et du Canton Jura. We are grateful to Günter Schweigert, Ulla Schudack and Lukas Hottinger for taxonomic assignment of ammonites, ostracodes and foraminifera. We thank also Bernhard Hostettler for providing very important ammonites and very helpful field trips. Thanks to the colleagues Johann Fleury, Sebastian Hinsken, Achim Reisdorf, Almar de Ronde and Kamil Ustaszewski for discussions and logistic support. Special thanks to Pascal Tschudin for discussions and providing material. André Strasser and Raymond Enay are thanked for constructive reviews of an earlier version of the manuscript. The FAG Basel is thanked for financial support. 


\section{REFERENCES}

Aigner, T. 1985: Storm depositional systems; dynamic stratigraphy in modern and ancient shallow-marine sequences. Springer Verlag, 174 p.

AllenBACH R.P. 2002: The ups and downs of "tectonic quiescence"; recognizing differential subsidence in the epicontinental sea of the Oxfordian in the Swiss Jura Mountains. Sedimentary Geology 150 (3-4), 323-342.

Allia, V. 1996: Sedimentologie und Ablagerungsgeschichte des Opalinustons in der Nordschweiz. PhD Thesis, Geol.-Palaeontol. Inst., University Basel, Switzerland, $185 \mathrm{p}$.

BAthurst, R.G.C. 1971: Carbonate sediments and their diagenesis. Developments in Sedimentology 12, $620 \mathrm{p}$.

Bernier, P. 1984: Les formations carbonatees du Kimmeridgien et du Portlandien dans le Jura meridional; stratigraphie, micropaleontologie, sedimentologie. Université Claude Bernard, Lyon, France. Documents des Laboratoires de Geologie 92, 802 p.

Burkhalter, R.M. 1996: Die Passwang-Alloformation (oberes Aalenien bis unteres Bajocien) im zentralen und nördlichen Schweizer Jura. Eclogae Geologicae Helvetiae 89(3), 875-934.

Chevalier, T. 1989: Les formations carbonatées de la séquence ptérocerienne (Kimméridgien pars) dans le Jura francais et les régions voisines. $\mathrm{PhD}$ Thesis, Cahiers de l'Institut Catholique de Lyon; Association des Facultes Catholiques de Lyon, France, 194 p.

Colombie, C. 2002: Sédimentologie, stratigraphie séquentielle et cyclostratigraphie du Kimméridgien du Jura suisse et du Bassin vocontien (France): relations plate-forme-bassin et facteurs déterminants. PhD Thesis, GeoFocus 4, 198 p.

Desor, E. \& Gressly, A. 1859: Etudes géologiques sur le Jura neuchâtelois. Mém. Soc. Sci. nat. Neuchâtel 4, 1-159.

DunHAM, R.J. 1962: Classification of carbonate rocks according to depositional texture. In: Classification of carbonate rocks - A symposium (Ed. by. HAM, W.E.). Memoir - Amer. Assoc. Petroleum Geol. 1, 108-121.

FlÜGEL, E. 1982: Microfacies Analysis of Limestones. Springer-Verlag, 633 p.

Frakes, L.A. Francis, J.E. \& Syktus, J.I. 1992: Climate modes of the Phanerozoic; the history of the Earth's climate over the past 600 million years: Cambridge, United Kingdom, Cambridge Univ. Press, 274 p.

GonZales, R. 1993: Die Hauptrogenstein-Formation der Nordwestschweiz (mittleres Bajocien bis unteres Bathonien), PhD Thesis, Geol.-Palaeontol. Inst., University Basel, Switzerland, 188 p.

Gramann, F. Heunisch, C. Klassen, H. Kockel, F. Dulce, G. Harms, F.J. Katschorek, T. Moennig, E. Schudack, M. Schudack, U. Thies, D. Weiss, M. \& Hinze, C. 1997: Das Niedersaechsische Oberjura-Becken Ergebnisse interdisziplinaerer Zusammenarbeit. Zeitschrift der Deutschen Geologischen Gesellschaft 148(2), 165-236.

Greppin, J.B. 1870: Description géologique du Jura bernois et de quelques districts adjacent. In: Matér. Carte géol. Suisse 8, 1-357.

Gygi, R.A. 1982: Sedimentation und Facies des Spaeten Jura im zentralen Juragebirge (Exkursion A am 15. und 16. April 1982). Jahresberichte und Mitteilungen des Oberrheinischen Geologischen Vereines 64, 17-28.

- 1995: Datierung von Seichtwassersedimenten des Spaeten Jura in der Nordwestschweiz mit Ammoniten. Eclogae Geologicae Helvetiae 88(1), $1-58$.

- 2000b: Integrated stratigraphy of the Oxfordian and Kimmeridgian (Late Jurassic) in northern Switzerland and adjacent southern Germany. Denkschriften der Schweizerischen Akademie der Naturwissenschaften 104, $151 \mathrm{p}$.

- 2000c: Annotated index of lithostratigraphic units currently used in the Late Jurassic of northern Switzerland. Eclogae Geologicae Helvetiae 93(1), 125-146.

Gygi, R.A. CoE, A.L. \& VAIL, P.R. 1998: Sequence stratigraphy of the Oxfordian and Kimmeridgian stages (Late Jurassic) in northern Switzerland. In: Mesozoic and Cenozoic sequence stratigraphy of European basins. (DE Graciansky, P. C. Hardenbol, J. Jacquin, T. \& Vail, P. R.). SEPM Special Publication 60, 527-544.

Gygi, R.A. \& Persoz, F. 1986: Mineralostratigraphy, litho- and biostratigraphy combined in correlation of the Oxfordian (Late Jurassic) formations of the Swiss Jura Range. Eclogae Geologicae Helvetiae 79(2), 385-454.
HÄFELI, C. 1966: Die Jura/Kreide-Grenzschichten im Bielerseegebiet (Kt. Bern). Eclogae Geologicae Helvetiae 59(2), 565-695.

Hantzpergue, P. Atrops, F. \& EnAy, R. 1997: Biozonations; Kimméridgien. In: Biostratigraphie du Jurassique ouest-européen et méditerranéen; zonations parallèles et distribution des invertébrés et microfossiles (CAriou, E. \& Hantzpergue, P.). Bulletin des Centres de Recherches Exploration-Production Elf-Aquitaine, Mémoire 17, 87-96 \& 148-151.

Harris, P.M. \& KowaliK, W.S. 1994: Satellite images of carbonate depositional settings: Examples of reservoir- and exploration-scale geologic facies variation. AAPG Methods in Exploration Series, $11 \mathrm{p}$.

JANK, M. 2004: New insights into the development of the Late Jurassic Reuchenette Formation of NW Switzerland (late Oxfordian to late Kimmeridgian, Jura Mountains). PhD Thesis, Geol.-Palaeontol. Inst., University Basel, Switzerland, 121 p.

LAUBSCHER, H. 1963: Erläuterungen zum Gologischen Atlas der Schweiz. Blatt1085 St-Ursanne. In: Geologischer Atlas der Schweiz (Ed. by S.G. Kommission).

MarCou, J. 1848: Recherches géologiques sur le Jura salinois. Première partie. Mém. Soc. géol. France 3(1), 1-151.

MARTy, D. 2003: Le Secondaire (Mésozoïque) du Jura le long de la Transjurane avec recherche approfondie sur le site de Courtedoux - Sur Combe Ronde. Rapport d'activités, Paléontologie et Transjurane 2002. Rapport de l'Office du patrimoine historique, Section de Paléontologie 3, 1-52.

Marty, D. \& Diedrich, C. 2002: Fouilles paléontologiques dans les unités du Secondaire (Mésozoïque): Combe de Vâ tche Châ, Déblais du Tunnel du Banné. Rapport d'activités, Paléontologie et Transjurane 2001. Rapport de l'Office du patrimoine historique, Section de paléontologie 2, 1-13.

MeYer, C.A. 1989: Der Lebens- und Ablagerungsraum der Solothurner Schildkrötenkalke. Separatdruck aus dem 34. Heft der Mitteilungen der Naturforschenden Geselllschaftdes Kantons Solothurn 34, 185-190.

- 1990: Sauropod tracks from the Late Jurassic Reuchenette Formation (Kimmeridgian, Lommiswil, Kt. Solothurn) of northern Switzerland. Eclogae Geologicae Helvetiae 83(2), 389-397.

- 1993: A sauropod dinosuar megatracksite from the Late Jurassic of northern Switzerland. Ichnos 3, 29-38.

Meyer, M. 2000: Le Complexe récifal kimméridgien - tithonien du Jura méridional interne (France), évolution multifactorelle, stratigraphie et tectonique. Terre \& Environnement 24, 179 p.

Mouchet, P.O.J. 1995: Le Kimméridgien du Jura central. Mcrofaciès, minéralogie et interprétation séquentielle. PhD Thesis, Université de Neuchâtel, Switzerland, 204 pp.

- 1998: Stratigraphy and mineralostratigraphy of the Kimmeridgian in the central Jura Mountains of Switzerland and eastern France. Eclogae Geologicae Helvetiae 91(1), 53-68.

NAGEL, R. \& LAuxmanN, U. 1990: Zur Verkieselung der oberjurassischen Korallen von Wuerttemberg. Neues Jahrbuch fuer Geologie und Palaeontologie. Monatshefte 1990(10), 622-638.

Oertli, H.J. 1959: Malm-Ostracoden aus dem schweizerischen Juragebirge. Denkschr. schweiz. natf. Ges. 83(1), 1-44.

- 1985: Atlas des ostracodes de France (Paleozoique-Actuel). Bulletin des Centres de Recherches Exploration-Production Elf-Aquitaine, Memoire 9, $396 \mathrm{p}$.

PitTet, B. 1996: Contrôles climatiques, eustatiques et tectoniques sur des systèmes mixtes carbonates-siliciclastiques de plate-forme: exemples de l'Oxfordien (Jura Suisse, Normandie, Espagne). PhD Thesis, University Fribourg, Switzerland, 258 p.

Purdy, E.G. 1963a: Recent calcium carbonate facies of the Great Bahama Bank; [Part] 1, Petrography and reaction groups. Journal of Geology 71(3), 334-355.

- 1963b: Recent calcium carbonate facies of the Great Bahama Bank; [Part] 2, Sedimentary facies. Journal of Geology 71(4), 472-497.

Schudack, M.E. \& SchudackC, U. 1995: Late Jurassic and Berriasian ostracod biogeography in northwestern Central Europe. In: Ostracoda and biostratigraphy; proceedings. (Ed. by RIHA, J.). 12 ${ }^{\text {th }}$ International Symposium on Ostracoda, 99-109.

SCHUdDAK, U. 1994: Revision, Dokumentation und Stratigraphie der Ostracoden des nordwestdeutschen Oberjura und Unter-Berriasium. In: Berliner Geowissenschaftliche Abhandlungen E, 193 p. 
Schweigert, G. \& Callomon, J.H. 1997: Der bauhini-Faunenhorizont und seine Bedeutung für die Korrelation zwischen tethyalem und subborealem Oberjura. Stuttgarter Beitr. Naturk. (B) 247, 1-69.

"SPA" 2001: Rapport 2000, Premières activités - Paléontologie et Transjurane No 1. Rapport de l'Office du patrimoine historique, Section de Paléontologie (Porrentruy, Switzerland).

Strasser, A. Pittet, B. Hillgaertner, H. \& Pasquier, J.B. 1999: Depositional sequences in shallow carbonate-dominated sedimentary systems; concepts for a high-resolution analysis: Sedimentary Geology 128 , 201-221.

Sulser, H. \& Meyer, C. 1998: Taxonomy and palaeoecology of terebratulid brachiopods (Sellithyris subsella-group) from the Late Jurassic of northwestern Switzerland. Eclogae Geologicae Helvetiae 91(3), 439-451.

Thalmann, H. 1966: Gliederung und Fazies des obersten Malm (Reuchenette- und Twannbachformation) im suedlichen Berner und Solothurner Jura. Eclogae Geologicae Helvetiae 59(2), 931-934.

Thurmann, 1832: Essai sur les soulèvements jurassiques de Porrentruy. Impr. F. G. Levrault: Strasbourg.

Tschudin, P. 2001: Teil II: Geländearbeiten im Schweizer Jura: Profilaufnahme Glovelier (JU). Diploma Thesis, University Bern, 59-109.

Wanless, H.R. Tedesco, L.P. \& Tyrrell, K.M. 1988: Production of subtidal tubular and superficial tubular tempestites by Hurricane Kate, Caicos Platform, British West Indies. Journal of Sedimentary Petrology 58, 739-750.
WeIss, M. 1995: Stratigraphie und Mikrofauna im Kimmeridge SE-Niedersachsens unter besonderer Berücksichtigung der Ostracoden. PhD Thesis, Geowissenschaftliche Institute der Technischen Universität Clausthal, Clausthal-Zellerfeld, $274 \mathrm{p}$.

- 1996: Neue Ostracoden aus dem Kimmeridgium NW-Deutschlands. Palaeontologische Zeitschrift 70(3-4), 461-474.

- 1997: Die biostratigraphische Einstufung der Grenze Korallenoolith/ Kimmeridge in NW-Deutschland; Kenntnisstand und neue Ergebnisse. Zeitschrift fuer Geologische Wissenschaften 25(1-2), 109-120.

WetZel, A. \& Aigner, T. 1986: Stratigraphic completeness; tiered trace fossils provide a measuring stick. Geology 14(3), 234-237.

Wetzel, A. Allenbach, R. \& Allia, V. 2003: Reactivated basement structures affecting the sedimentary facies in a tectonically "quiescent" epicontinental basin; an example from NW Switzerland. Sedimentary Geology 157(1-2), 153-172.

Wetzel, A., Allia, V., Gonzalez, R. \& Jordan, P. 1993, Sedimentation und Tektonik im Ostjura. Eclogae Geologicae Helvetiae 86, 313-332.

WILSON, J.L. 1975: Carbonate facies in geologic history. Springer-Verlag, 471 $\mathrm{p}$.

ZIEGLER, P.A. 1990: Geological Atlas of Western and Central Europe. Shell Internationale Petroleum Maatschappij B.V. Den Haag, 239 p.

Manuscript received August 27, 2004

Revision accepted April 21, 2006

Published Online First October 13, 2006

Plate 1. Characteristics of eight intervals of the Reuchenette Formation (scales: $\Delta \approx 2.5 \mathrm{~cm}$, hammer, motorbike, pencil).

Picture a: Thalassinoides Limestones - Reddish brown pseudo-oolitic material (arrows) within finer grained, grey matrix. Note the blocky cements (1) next to coarser material in the Thalassinoides burrows (base L'Alombre aux Vaches).

Picture b: "Nautilidenschichten" - Thick to massive marly limestones with nodular bedding (Fontenais).

Picture c: Lower Grey and White Limestones - The topmost thick limestone bed correlates with bed VEN-41 in Vendlincourt. The Banné Marls follow on the top of this bed and are rarely visible (covered) (Chevenez).

Picture d: Banné Marls - Large bivalve at the top is a Pholadomya sp. (Cras d'Hermont, block between motorway and car shop).

Picture e: Nerinean Limestones - Chalky Nerinean Limestone "sensu stricto" with internal molds of Nerinean gastropods (arrows; bed CHV-80, La Combe).

Picture f: Virgula Marls (Sur Combe Ronde).

Picture g: Coral Limestones - White chalky thin-bedded blocky fracturing limestone (La Combe). Thin marl seams separate beds.

Picture h: Oyster Limestones - Storm intercalation in bioclastic mud- to wackestone. The shell pods of Nanogyra sp. (arrows) and some other shells are caused by bioturbation (bed CHV-2900, La Combe). 

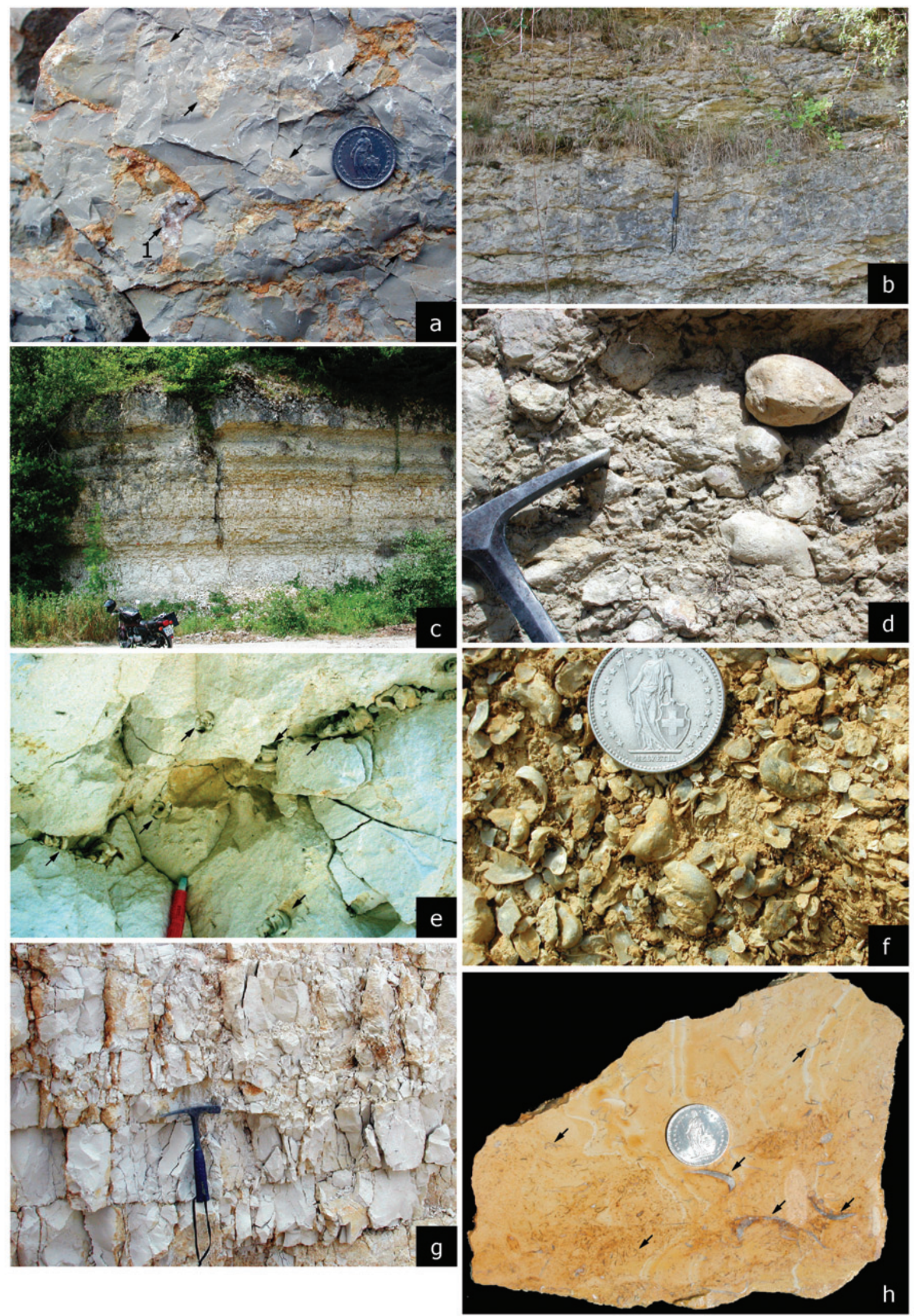
